\title{
Borehole temperatures at the Colle Gnifetti core-drilling site (Monte Rosa, Swiss Alps)
}

\author{
Wilfried HAEBerli AND MARTIN FunK \\ Versuchsanstalt für Wasserbau, Hydrologie und Glaziologie, ETH-Zentrum, \\ CH-8092 Zürich, Switzerland
}

\begin{abstract}
Measured englacial temperatures at the Colle Gnifetti core-drilling site are presented and compared with model calculations concerning possible effects of 20 th century warming. The firn/ice saddle at the $124 \mathrm{~m}$ deep saddle borehole is cold throughout with a mean annual surface temperature near $-14^{\circ} \mathrm{C}$ and a basal temperature slightly below $-12^{\circ} \mathrm{C}$. Influence of refreezing meltwater is weak and limited to near-surface formation of ice layers (recrystallization-infiltration). Temperature gradients in the saddle borehole are positive and increase from $0.015^{\circ}$ to $0.019^{\circ} \mathrm{C} \mathrm{m}^{-1}$ between $30 \mathrm{~m}$ depth and bedrock, corresponding to a mean vertical heat flow of around $50 \mathrm{~mW} \mathrm{~m}^{-2}$. The observed temperature profile is close to steady-state conditions. It can well be reproduced with time-dependent model calculations using mean annual air temperatures from the nearby weather station of Grand St. Bernard within the main chain of the Swiss Alps, but it significantly deviates from similar calculations based on Säntis data, reflecting developments of air temperatures on the northern slope of the Alps. 20th century warming of cold Alpine firn seems to be much less pronounced than in polar areas, where strong heat-flow anomalies are commonly observed.
\end{abstract}

\section{INTRODUCTION}

Ice-core records from Alpine glaciers represent important information concerning Man's long-term impact on his local atmospheric environment. While glacier sites in the tropics and in northwest Canada primarily provide useful paleoclimatic records, a clear record of atmospheric pollution until today is only available from glacier sites in the European Alps, especially from Colle Gnifetti, Monte Rosa, Swiss/Italian Alps (Wagenbach, 1989). At this core-drilling site (Fig. 1) investigated since 1976 (Oeschger and others, 1978), significant down-core decrease in background level of liquid conductivity as well as in mean acidity level, sulfate, and nitrate reflects the change caused by Man-made emissions of the corresponding mineral acid precursors (Wagenbach and others, 1988), with relative peak values having been reached around the mid-1970s (Schotterer and others, 1985). An important part of the interdisciplinary studies on Colle Gnifetti aims at describing the rather complex characteristics of firn and ice as embedding agent of such environmental, i.e. climatic and air-chemical, information on the relatively small and wind-exposed high-altitude saddle at $4450 \mathrm{~m}$ a.s.l. Thereby, englacial temperatures are of fundamental importance due to their being coupled with firn stratigraphy (Haeberli and others, 1983), surface mass balance (Alean and others, 1984), as well

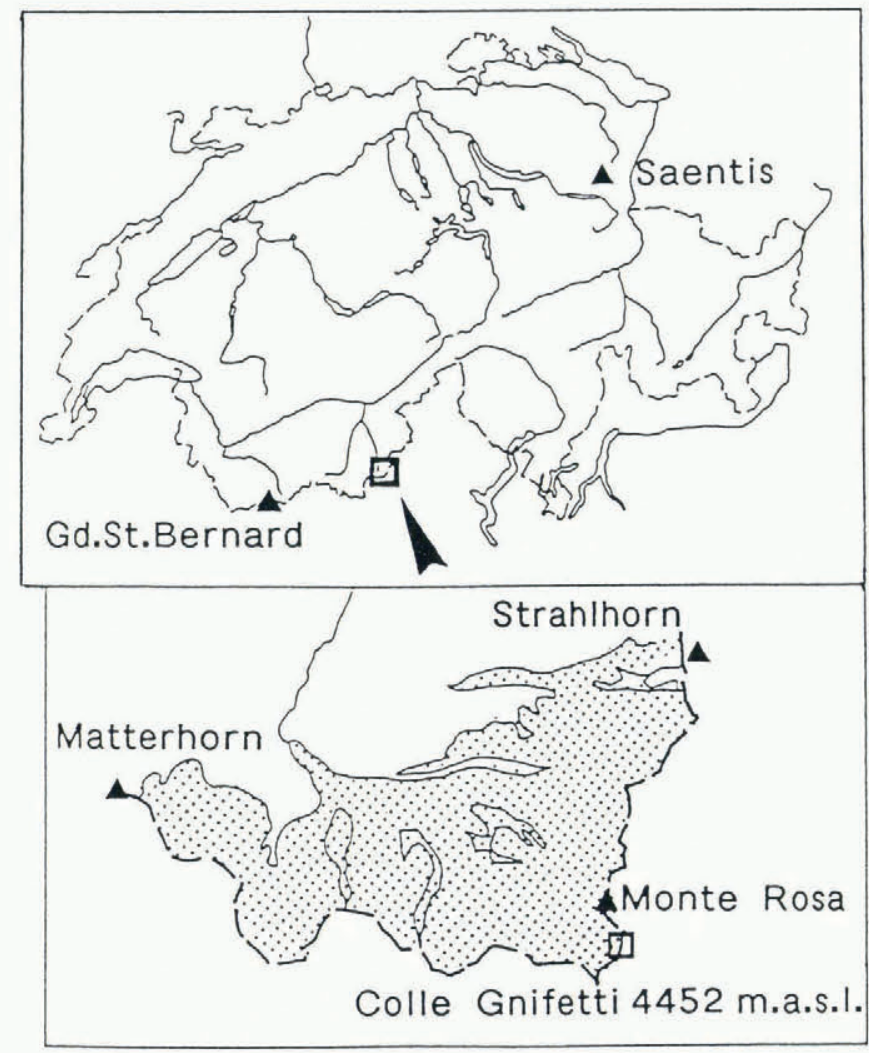

Fig. 1. Location map of Colle Gnifetti. 
as geometry, flow, and age of firn and ice (Haeberli and others, 1988).

Besides their importance as essential background information, firn and ice temperatures at Colle Gnifetti are also interesting by themselves. Dry transformation of cold firn into low-density ice at high altitudes can greatly influence the composition and thermal state of polythermal valley glaciers (Haeberli, 1976; Blatter and Haeberli, 1984). Moreover, a continuation or even acceleration of 20 th century warming could lead to a general warming of high-altitude firn areas and thereby affect the stability of steep hanging glaciers in mountain regions (cf. Alean, 1985; Haeberli and Alean, 1985; Schweizer, 1988). In fact, strong thermal anomalies caused by 20th century warming are observable in Arctic firn areas (Robin, 1983; Blatter, 1987). Increased melt-layer frequency in cold Arctic firn seems to be coupled with such recent warming (Koerner, 1977) and has been observed on Colle Gnifetti - i.e. in cold mid-latitude firn - as well (Schotterer and others, 1981). Corresponding firn-temperature effects, however, have not been investigated so far in non-polar latitudes. The borehole on Colle Gnifetti now provides an opportunity for investigating the development of firn temperatures at a mid-latitude site during the 20th century, and its relation to air temperature.

The present paper describes borehole temperature measurements on Colle Gnifetti, draws conclusions with respect to the thermal condition of firn and ice formation at the core-drilling site, and discusses the results of model calculations concerning the development of highaltitude firn temperatures in the Alps during the recent past. In addition, a scenario of future warming is also modelled in view of future long-term firn-temperature monitoring.

\section{BOREHOLE TEMPERATURES}

On the basis of borehole temperatures measured in the tongue of Grenzgletscher and temperature data reported by Fisher $(1953,1954,1955)$ and Lliboutry and others (1976) from high-altitude sites in the Alps, the saddle area of the Colle Gnifetti core-drilling site was expected to be situated within the recrystallization-infiltration belt of Alpine firn facies and mean annual (surface) firn temperatures (=MAFT) to be about $-10^{\circ}$ to $-15^{\circ} \mathrm{C}$ (Haeberli, 1976). The first temperature measurements in a borehole drilled on Colle Gnifetti in 1976 with an electromechanical core drill down to $33 \mathrm{~m}$ depth confirmed these expectations (Oeschger and others, 1978): air temperature within the open borehole as measured on 9 September 1976, $15 \mathrm{~h}$ after termination of drilling activity and installation of thermistors, was $-14.4^{\circ} \mathrm{C}$ at $15 \mathrm{~m}$ depth, steadily increasing with depth to reach $-14.0^{\circ} \mathrm{C}$ at the bottom of the hole $(=\mathrm{BH})$. The hole with the thermistors was filled with snow and marked with a wooden pole. However, the pole soon disappeared for unexplained reasons, making a geodetic survey of the borehole coordinates and a repetition of the temperature measurements impossible. Extrapolation of the measured temperature profile using the temperature gradient $\left(0.025^{\circ} \mathrm{C} \mathrm{m}^{-1}\right)$ observed between $12 \mathrm{~m}$ and $\mathrm{BH}$ gives a mean surface temperature of roughly $-15^{\circ} \mathrm{C}$. This temperature value closely corresponds to the mean annual

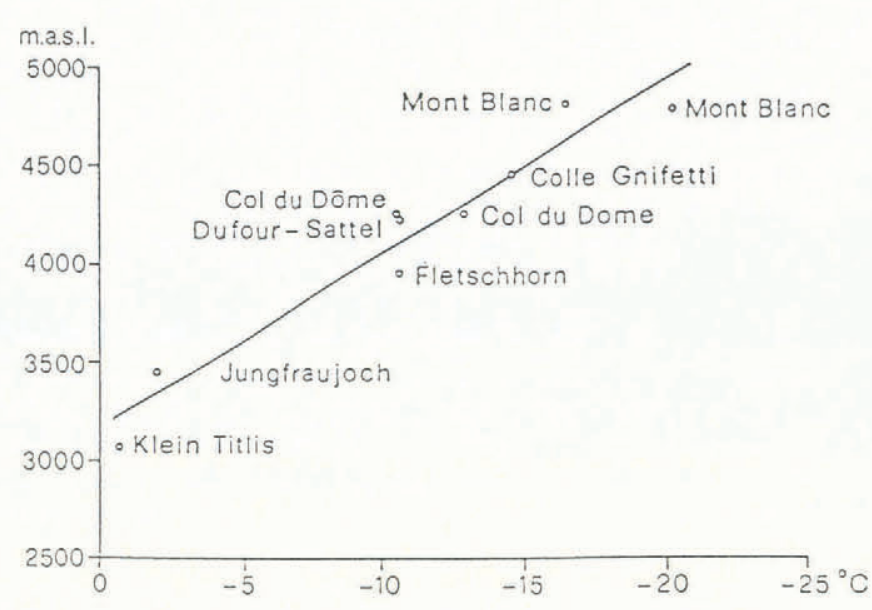

Fig. 2. Mean annual temperature of highaltitude firn and ice summits. Data are from Haeberli (1976), Haeberli and Alean 1985), and this paper. Horizontal gradients between individual sites are assumed to be negligible. The Mont Blanc information concerns two different sites in the summit area (cf. Lliboutry and others, 1976).

air temperature (= MAAT, $-14^{\circ}$ to $-14.5^{\circ} \mathrm{C}$ ) which can be estimated for this altitude using the commonly applied, but possibly too low (?), $0.65^{\circ} \mathrm{C} 100 \mathrm{~m}^{-1} \mathrm{en}$ vironmental lapse rate and a MAAT of $-8.5^{\circ} \mathrm{C}$ at the Jungfraujoch, $3580 \mathrm{~m}$ a.s.l., roughly $80 \mathrm{~km}$ north of Colle Gnifetti. Hence, the influence of meltwater production during snow deposition and firnification is weak and indeed limited to the formation of thin and horizontal, near-surface ice layers as indicated by the core stratigraphy (cf. also Fig. 7). A linear regression calculation of MAFT in wind-exposed Alpine summits, crests and saddles as a function of altitude (Fig. 2) gives a mean gradient of $1.06^{\circ} \mathrm{C} 100 \mathrm{~m}^{-1}$, i.c. 1.63 times higher than the assumed lapse rate of MAAT - probably an effect of tempcrature and altitude-dependent meltwater infiltration and refreezing. If one assumes that time variations in air temperature lead to corresponding vertical shifts in firn-temperature zones, an enhancement of MAFT changes by about 1.6 with respect to MAAT changes could be anticipated. In view of the strong snow erosion on the wind-exposed saddle, mean values of MAFT and accummulation ( $b=0.35$ m w.e. year $\left.{ }^{-1}\right)$ measured on Colle Gnifetti agree surprisingly well with values compiled by Herron and Langway (1980) for polar regions.

Two holes at a distance of $1 \mathrm{~m}$ apart were drilled into the saddle in 1977 with the same equipment as in 1976. The first hole reached a depth of $50 \mathrm{~m}$ and was used for testing the reliability of temperature measurements in open boreholes. The main uncertainties involved with this measurement technique concern the time necessary for thermal adjustment of the borehole after termination of thermal disturbance from (mechanical) drilling activity and the question of potential air convection with density inversions in the open borehole. On 21 August 1977, $25 \mathrm{~h}$ after the installation of the thermistor chain, temperatures were measured in the open borehole at depths of $20 \mathrm{~m}\left(-14.5^{\circ} \mathrm{C}\right), 30 \mathrm{~m}, 40 \mathrm{~m}$ and $50 \mathrm{~m}\left(-13.8^{\circ} \mathrm{C}\right)$. The hole was then filled with surface snow of about $-7^{\circ} \mathrm{C}$ 


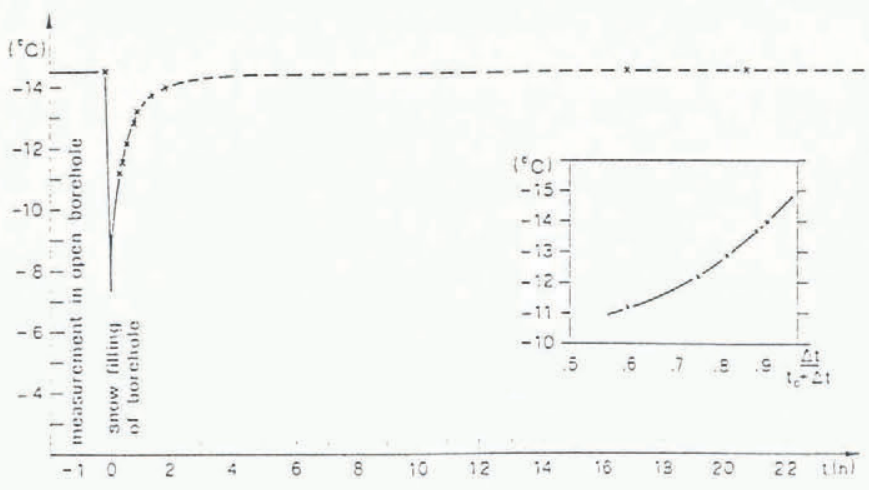

Fig. 3. Adjustment of borchole temperature at $20 \mathrm{~m}$ depth after snow filling of the borehole in August 1977. Inset: extrapolation of thermal. adjustment in the borehole (20 $\mathrm{m}$ depth) after snow filling following the common procedure for bottom-hole temperature measurements after Fertl and Wichmann (1977), for comparison, with $t_{0}$ as time of thermal disturbance (here by snow filling) and $\Delta t$ as time after snow filling.

and thermal adjustment observed during a $24 \mathrm{~h}$ period (Fig. 3). Complete thermal adjustment to within measuring accuracy $\left(0.1^{\circ} \mathrm{C}\right)$ took less than $17 \mathrm{~h}$ and temperatures in the snow-filled borehole remained stable within less than $0.06^{\circ} \mathrm{C}$ during the following 8 months until 13 April 1978. Temperatures closely matched those measured in the other borehole which was kept open. Two conclusions can be drawn from this experiment: (1) given the borchole diameter of about $115 \mathrm{~mm}$ and temperature gradients of $0.02-0.03^{\circ} \mathrm{C} \mathrm{m}^{-1}$, air-convection effects in the open borehole do not occur, and (2) thermal disturbance from mechanical core drilling and snow filling dissipate soon, i.e. within $24 \mathrm{~h}$ to less than the measurement error of one-tenth of a degree. It is, however, noteworthy that the commonly applied extrapolation scheme for correcting short-term borehole temperatures with respect to drilling disturbance (cf. Fertl and Wichmann, 1977 ) would have given a static borehole temperature which is too cold by several tenths of a degree (Fig. 3). The second borehole drilled in 1977 reached a depth of $65 \mathrm{~m}$, where the drill was lost due to mechanical failure. Temperatures in this open borehole were measured in April 1978 with a chain of ten thermistors which had been specially calibrated by the Swiss Federal Office of Metrology (Wabern, Bern) to a few hundredths of a degree. After installation, the chain was three times pulled up a short distance in order to enable measurements at $2 \mathrm{~m}$ intervals and always remained in place during $24 \mathrm{~h}$ before readings were taken. The temperature gradient below $40 \mathrm{~m}$ depth was $0.024^{\circ} \mathrm{C}$ and extrapolation of the temperature profile to the bed at about $95 \mathrm{~m}$ depth as first located in April 1978 by radio-echo sounding (F. Thyssen, Münster, Germany) indicated basal ice temperatures of about $-12^{\circ}$ to $-13^{\circ} \mathrm{C}$ (Blatter and Haeberli, 1984).

Near-surface firn temperatures over the whole saddle area were estimated in 1980 by measuring temperature differences with respect to the 1977 drill site in $2 \mathrm{~m}$ deep holes mechanically drilled in a regular grid with a $50 \mathrm{~m}$ mesh width for the installation of survey stakes. Significantly warmer temperatures than those measured at the 1977 drill site were only encountered at the foot of Zumsteinspitze. No simple relation between the distribution of surface temperatures and the amount of incoming solar radiation was found, possibly due to the positive coupling of surface-energy input, melt-layer frequency and mass balance (protection of cold snow against wind crosion; Alean and others, 1984). Using the so-measured differences in near-surface temperature in combination with the information on $10 \mathrm{~m}$ temperatures and temperature gradients obtained from the 1977 boreholes as described above and more extensive radio-echo data on bedrock depth, a rough guess of basal temperatures was made (Fig. 4). This procedure neglects effects due to frictional heating and ice advection; in addition, results from radio-echo soundings were later adjusted to results from deep drilling (cf. Haeberli and others, 1988) and, finally, temperature gradients in the later measured saddle borehole to bedrock turned out to be, for so far unknown reasons, lower than those determined in the 1976 and 1977 boreholes. Thus, the calculated basal temperatures are approximate and, in fact, about $1^{\circ} \mathrm{C}$ lower than the later calculated two-dimensional profile (cf. Fig. 5). They nevertheless clearly indicate that the ice base around the drill site is far below the melting point everywhere and, hence, that sliding at the glacier bed can be neglected in

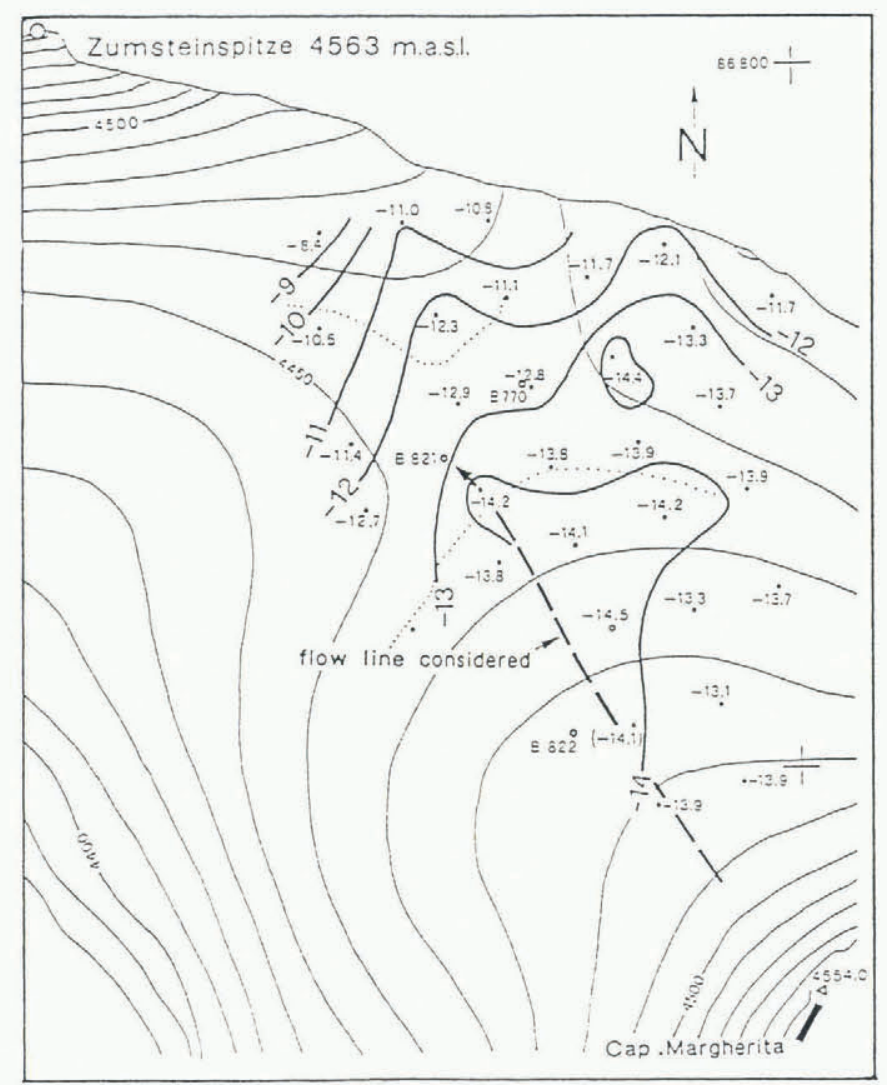

Fig. 4. Estimates of basal ice temperatures at the Colle Gnifetti core-drilling site (point information and isolines in ${ }^{\circ} \mathrm{C}$ ); dashed line with arrow indicates main flowline leading to the saddle borehole (B 821); B 770 and B 822 are other boreholes drilled in 1977 and 1982 (cf. text). 


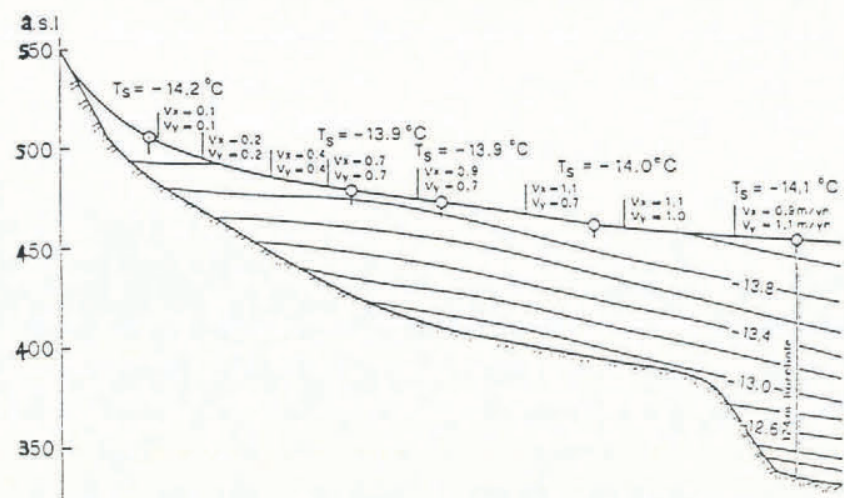

Fig. 5. Geometry, ice-flow velocities ( $v_{x}$ is horizontal, $v_{y}$ is vertical component), $10 \mathrm{~m}$ temperatures $\left(T_{s}\right)$ and two-dimensional calculation of englacial temperatures along the flowline leading to the saddle borchole (cf. Hacberli and others, 1988, for depth and velocity data).

attempts to model the temperature, flow and age of firn and ice in the saddle area.

1982 saw the completion of two boreholes reaching a silty layer which is assumed to represent the basal layer immediately above bedrock: one $124 \mathrm{~m}$ deep borehole (B 821) was drilled on the Swiss side of the saddle, about $65 \mathrm{~m}$ southwest of the 1977 boreholes (Schotterer and others, 1985), and another one (B 822), $65 \mathrm{~m}$ deep, at a place about $180 \mathrm{~m}$ upslope along approximately the same flowline as estimated from stake surveys (Haeberli and others, 1988). Temperature measurements were carried out in the open $124 \mathrm{~m}$ borehole (B 821) in 1983 with a similar precisely calibrated thermistor chain as used in 1978. Comparison of overlapping readings at $6 \mathrm{~m}$ intervals between 42 and $90 \mathrm{~m}$ depth indicates that the accuracy of absolute values is within $0.2^{\circ} \mathrm{C}$ and that temperature differences measured at various depths using the same thermistor are reproducible within $0.05^{\circ} \mathrm{C}$. Figure 6 summarizes the results: temperature is $-14.1^{\circ} \mathrm{C}$ at $12 \mathrm{~m}$ depth and steadily increases to $-12.2^{\circ} \mathrm{C}$ at the glacier bed in fairly good agreement with previously calculated basal temperatures. Temperature gradients are lower than in the 1976 and 1977 boreholes, increasing from $0.015^{\circ} \mathrm{C} \mathrm{m}^{-1}$ between 30 and $60 \mathrm{~m}$ depths to $0.018^{\circ} \mathrm{C} \mathrm{m}^{-1}$ between 60 and $90 \mathrm{~m}$ depths and to $0.019^{\circ} \mathrm{C} \mathrm{m}^{-1}$ between $90 \mathrm{~m}$ and $\mathrm{BH}$ (cf. Table 1). Heat flow along borehole axis varies around a value of about $50 \mathrm{~mW} \mathrm{~m}^{-2}$, a low value which must be expected at such exposed topographic peaks (cf. Bodmer and Rybach, 1984). Using these measurements and applying corrections for paleoclimatic effects from the Ice Age as discussed by Haeberli and others (1984), the thickness of subglacial permafrost on top of Monte Rosa can be roughly estimated at about $1000-1500 \mathrm{~m}$.

In order to parameterize flow models for temperature calculations, six shallow boreholes were mechanically drilled and $10 \mathrm{~m}$ temperatures measured along the surface flowline in 1985 . The results are compiled in Figure 5 and confirm that MAFT varies within a few tenths of a degree only, i.e. within the measuring accuracy, along the flowline leading to the $124 \mathrm{~m}$ borchole. A $10 \mathrm{~m}$ temperature, warmer by about $2^{\circ} \mathrm{C}$, was measured

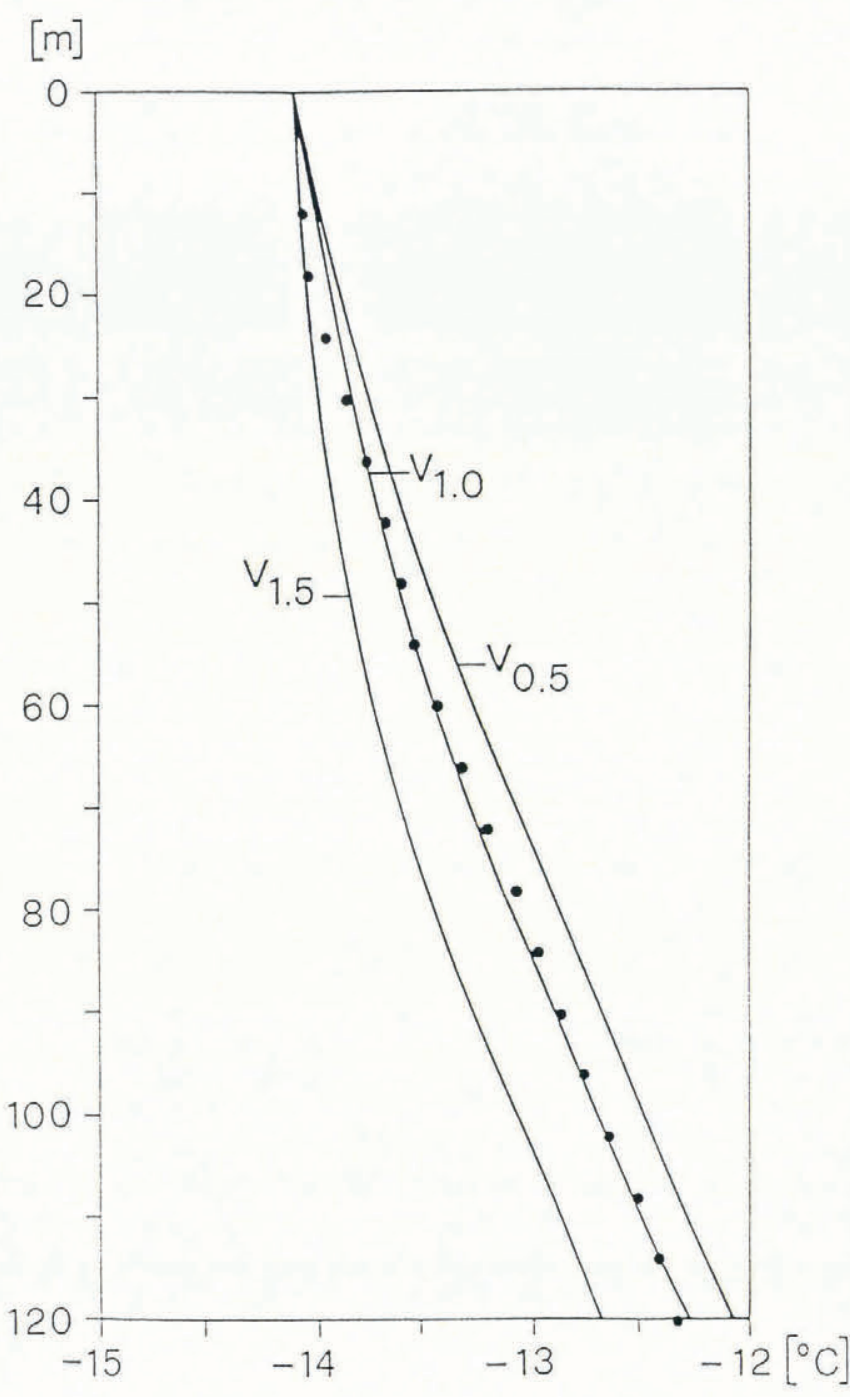

Fig. 6. Measured borchole temperatures (dots) and calculated stcady-state profiles (solid lines) $\left(v_{0.5}, v_{1.0}\right.$ and $v_{1.5}$ are vertical surface velocities of $0.5,1.0$ and 1.5 myear $^{-1}$ ) for the drilling site at Colle Gnifetti (saddle borehole B 821).

Table 1. Measured and calculated temperature gradients $\left({ }^{\circ} \mathrm{Ckm}^{-1}\right)$ on Colle Gnifetti

\begin{tabular}{cccccc} 
Depth & s.s. & Measured & GSB & $S$ & $U$ \\
$\mathrm{~m}$ & & & & & \\
\hline $30-60$ & $14-19$ & $14-16$ & $14-19$ & $6-11$ & $4-9$ \\
$60-90$ & $19-21$ & $17-19$ & $19-21$ & $11-13$ & $2-4$ \\
$90-120$ & $20-21$ & $18-20$ & $20-21$ & $16-17$ & $7-8$
\end{tabular}

cf. text and Figure 9 for explanation and discussion. 
at the foot of the Zumsteinspitze slopes only. At the $124 \mathrm{~m}$ borehole from $1980,10 \mathrm{~m}$ temperature as measured in 1985 was $0.7^{\circ} \mathrm{C}$ colder than in 1983 . This difference is assumed to be an effect of short-term temperature variations and has been accordingly corrected for in all shallow boreholes along the flowline when used for twodimensional model calculations.

\section{MODEL CALCULATIONS}

Englacial temperature distribution is mainly determined by glacier geometry, the velocity field, snow/firn ice conditions with the corresponding physical properties involved, climatic conditions at present and in the past, and geothermal heat flow. These parameters are interrelated in a complex manner: climatic changes directly influence the glacier geometry, the distribution of firn and ice, and the thermal conditions at the surface; indirectly, they also affect advective heat transport and frictional heating due to ice flow. Complex feed-back mechanisms are involved including long-term changes of geothermal heat flow. In order to get a view of thermal conditions in an existing ice body with limited data available, several simplifications must be introduced for modelling purposes. The consequences of such commonly used simplifications have been discussed by Paterson (1981) (cf. also Ritz, 1987; Waddington, 1987).

The temperature distribution in an isotropic ice body with defined geometry and boundary conditions is decribed by the heat equation (Carslaw and Jaeger, 1959):

$$
\frac{\partial T}{\partial t}=\nabla(\kappa \cdot \nabla T)-\vec{v} \cdot \nabla T+\frac{Q}{\rho c}
$$

where $\kappa$ is thermal diffusivity, $\vec{v}$ is velocity vector, $Q$ is internal heat generation, $\rho$ is density of ice, $c$ is specific heat capacity, $T$ is temperature and $t$ is time. Colle Gnifetti certainly was a cold accumulation zone during the Holocene, i.e. during the entire period considered in the following. The temperature profile measured in the $124 \mathrm{~m}$ deep borehole B 821 (Fig. 6) is concave with positive gradients increasing with depth. It resembles a typical near-steady-state temperature profile in a cold accumulation area with little influence of horizontal heat advection. A one-dimensional approach is therefore used to model a steady-state profile. Timedependent calculations are then performed with the onedimensional model in order to investigate effects of seasonal temperature variations as well as secular warming trends. A two-dimensional steady-state calculation along the main flowline leading to the borehole (the geometry used is illustrated in Figure 5; cf. Haeberli and others, 1988) gives an impression of the temperature field between the borehole and the bergschrund.

\section{STEADY-STATE CONDITION}

Considering the small horizontal velocity $\left(1\right.$ m year $\left.^{-1}\right)$ and the almost constant $10 \mathrm{~m}$ temperatures along the flowline, a one-dimensional model indeed appears to be adequate for calculating the temperature profile. The one-dimensional temperature profile with density/depthdependent thermal diffusivity is governed by Equation (2):

$$
\frac{\partial T}{\partial t}=\kappa(y) \frac{\partial^{2} T}{\partial y^{2}}+\frac{\partial \kappa}{\partial y} \frac{\partial T}{\partial y}-v_{y} \frac{\partial T}{\partial y}+\frac{Q}{\rho c} .
$$

The dependence of thermal diffusivity on temperature is weak and, hence, is not considered here. Equation (2) was solved using the explicit finite-difference method (Smith, 1978; Mitchell and Griffiths, 1980) by running a time-dependent model until transients were small. The calculations were done using a one-dimensional grid with $2 \mathrm{~m}$ intervals $\Delta y$. The time steps $\Delta t$ were chosen to meet the stability criterion (Morton, 1980):

$$
\Delta t<\frac{1}{2}\left(\Delta y^{2} / \kappa\right) \text {. }
$$

A steady-state situation $(\partial T / \partial t=0)$ and the following boundary conditions were assumed:

(1) Constant surface temperature $T_{\mathrm{s}}=-14.1^{\circ} \mathrm{C}$, as selected to fit the lower half of the measured profile.

(2) Thermal diffusivity as a function of density according to Paterson (1981, p. 186, equation 1) and Haeberli and others (1988, fig. 2).

(3) Bottom temperature gradient of the ice.

$$
(\partial T / \partial y)_{\mathrm{b}}=0.019^{\circ} \mathrm{Cm}^{-1} \text {. }
$$

(4) Vertical surface velocity $v_{y}\left(y_{0}\right)=1 \mathrm{~m} y e a r^{-1}$ according to the stake survey: the vertical velocity profile described in Haeberli and others (1988) was used to include effects due to firn compaction:

$$
\begin{aligned}
v_{y}(y) & =v_{y}\left(y_{0}\right) \frac{\mu}{\mu+S(y)}\left[1-\frac{\lambda y-S(y)}{\lambda H-1+\mu}\right] \\
S(y) & =(1-\mu)\left(1-\mathrm{e}^{-\lambda \cdot y}\right) \\
\mu & =0.52 \text { and } \lambda=0.06 .
\end{aligned}
$$

where $H$ is glacier thickness, $\mu$ is ratio between surface density and maximum ice density, and $\lambda^{-1}$ is scaledepth parameter of density increase (cf. Ling, 1985).

(5) In view of the various complications involved (e.g. three-dimensional effects, horizontal gradient of geothermal heat, incompleteness of velocity and temperature input data), frictional heating $(Q)$ was calculated in a simplified way ( $\dot{\epsilon}$ is strain rate, $\tau$ is shear stress):

$$
\begin{aligned}
Q & =2 \dot{\epsilon}_{x y} \tau_{x y}(\text { Paterson, 1981, p. 200) } \\
\tau_{x y} & =\rho g \tau \sin \alpha
\end{aligned}
$$

where $y$ is local depth and $\alpha$ is surface slope along the main (lower) part of the flowline,

$$
\dot{\epsilon}_{x y}=A \tau_{x y}{ }^{3}, A=5 \times 10^{-24}\left(\mathrm{~Pa}^{-3} \mathrm{~s}^{-1}\right)
$$

(Paterson, 1981 p. 39).

Figure 6 compares the measured (dots) and the calculated temperature profiles (solid line). Measured and calculated values remain within measurement accuracy $\left(0.2^{\circ} \mathrm{C}\right)$ : the calculation strongly suggests that the meas- 
ured profile at Colle Gnifetti is close to a steady state. The curves $v_{0.5}$ and $v_{1.5}$ are results of a model run with $v\left(y_{0}\right)=0.5$ and 1.5 to show how the temperature profile is influenced by changes in the accumulation rate and submergence velocity without changing the geometry. In reality, average accumulation rates may have varied by less than $\pm 20 \%$ with a slight tendency towards a $10 \%$ increase during the 20th century (Schotterer and others, 1981 , fig. 6). The chosen range of $\pm 50 \%$ is therefore extreme and, hence, also illustrates the uncertainty range of the calculation due to other effects (such as, for instance, more complicated velocity/depth functions). By considering the two extreme values for the accumulation rate, the obtained temperature difference at the bottom is about $0.5^{\circ} \mathrm{C}$. It can be concluded that changes in the accumulation rate have a small effect on the temperature profile and, therefore, the temperature ficld in this area is primarily governed by the surface temperature. The influence of secular thickness changes cannot realistically be investigated due to the lack of quantitative input data. From the reconstructed history of 20 th century accumulation rates (Schotterer and others, 1981) and old photographs (Haeberli and others, 1988), however, geometric changes of the firn saddle during the past century can be assumed to have been rather unimportant. The striking difference between the near-steady-state condition at Colle Gnifetti and the strong anomalies observed in firn-temperature profiles from the Arctic points to the fact that 20th century warming of cold firn was much less pronounced in the Alps than at higher latitudes of the Northern Hemisphere.

A two-dimensional model calculation was performed to obtain a general picture of the temperature field along the flowline. The two-dimensional stationary temperature field is governed by the equation:

$$
\begin{gathered}
\kappa(y) \frac{\partial^{2} T}{\partial x^{2}}+\kappa(y) \frac{\partial^{2} T}{\partial y^{2}}+\frac{\partial \kappa}{\partial y} \frac{\partial T}{\partial y} \\
-v_{x} \frac{\partial T}{\partial x}-v_{y} \frac{\partial T}{\partial y}+\frac{Q}{\rho c}=0 .
\end{gathered}
$$

Equation (3) was solved using finite differences (Runchal, 1972; Mitchell and Griffiths, 1980). A two-dimensional lattice was defined, with a horizontal grid interval $\Delta x=$ $5 \mathrm{~m}$ and a vertical interval $\Delta y=2 \mathrm{~m}$. The boundary of the area is given by polygonal lines defined by the corner points. The calculation was based on the assumptions of constant near-surface temperatures and a constant bottom-temperature gradient of $0.019^{\circ} \mathrm{C} \mathrm{m}^{-1}$. The velocity vector $\vec{v}(x, y)$ was calculated as described in Haeberli and others (1988) with zero sliding at the glacier bed.

The calculated temperature is shown in Figure 5. The isotherms are roughly parallel to the surface and basal temperature varies little in the saddle region, being below $-12^{\circ} \mathrm{C}$ everywhere. The contribution of horizontal advection is small because horizontal temperature gradients are insignificant. In fact, even weaker threedimensional effects (lateral advection at depth) may influence the borehole in the saddle area rather than the two-dimensional advection along the flowline considered here (Haeberli and others, 1988). It can therefore be

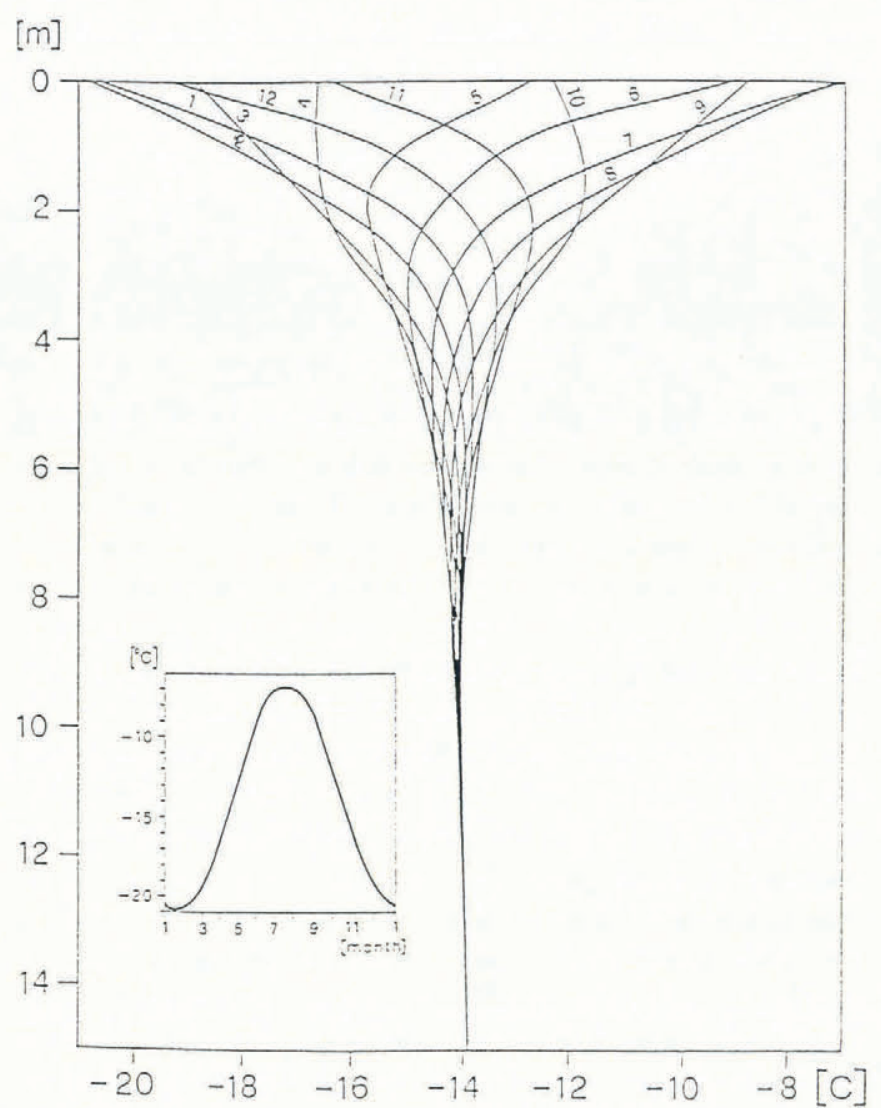

Fig. 7. Englacial temperature profiles for each month in the year. Inset: average annual surface-temperature variation at Colle Gnifetti as inferred from measured mean annual firn temperature in the saddle borehole (B 821) and air-temperature variations (monthly means) at Jungfraujoch.

assumed that horizontal advection is negligible with respect to temperatures in the saddle borehole.

\section{TIME-DEPENDENT EVOLUTION}

In order to estimate how deep the seasonal variations in surface temperature affect the measured borchole temperatures, a model calculation was performed using monthly means of air temperatures as recorded at Jungfraujoch (3576 ma.s.l, $46^{\circ} 33^{\prime} \mathrm{N}$; Aellen, 1988) and an annual mean surface temperature $T_{\mathrm{s}}=-14.1^{\circ} \mathrm{C}$ for the saddle borehole on Colle Gnifetti. Figure 7 shows temperature profiles for each month. Firn temperature obviously reaches melting conditions at the surface during daily cycles and under special energy-balance conditions only (radiation/wind; cf. Beck and others, 1988). Differences between annual extremes are $14^{\circ} \mathrm{C}$ at the surface, $1.5^{\circ} \mathrm{C}$ at $5 \mathrm{~m}$ depth, and less than $0.3^{\circ} \mathrm{C}$ at $10 \mathrm{~m}$ depth. Below a depth of $15 \mathrm{~m}$, seasonal temperature variations do not measurably deviate from the annual mean any more. Based on this result, the uppermost two points of the measured temperature profile are considered to be affected by seasonal temperature variations and are therefore disregarded in the following discussion of long-term temperature changes.

The same one-dimensional model as described above was used in combination with a time-dependent surface 

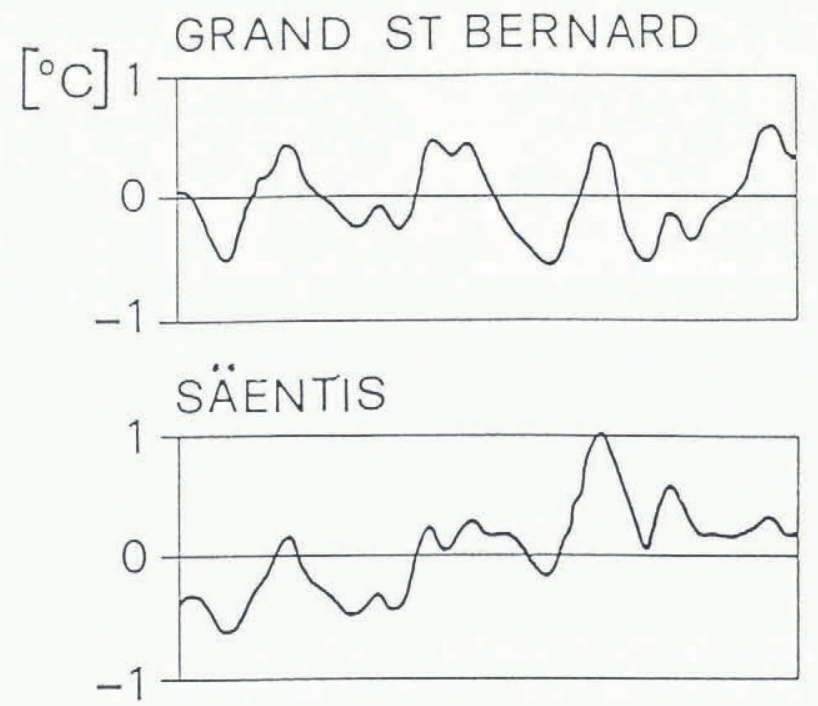

\section{UPERNAVIK}

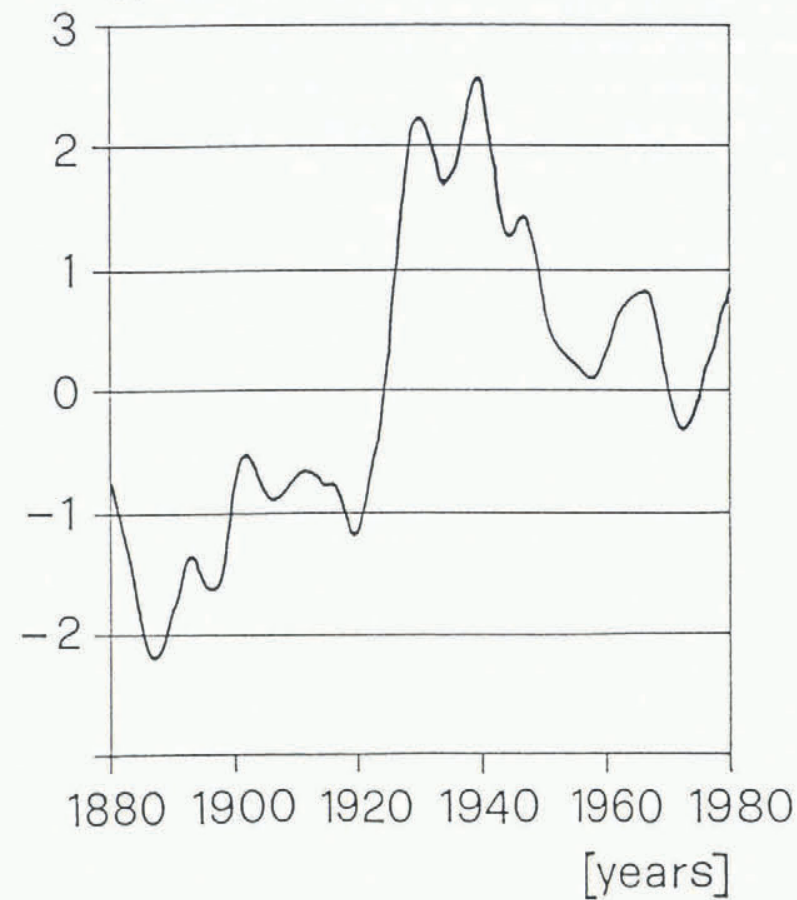

Fig. 8. Long-term series of the deviation of mean annual air temperatures at Grand St. Bernard (GSB), Säntis (S) and Upernavik (U). The three series have been smoothed with a nine-point binomial filter.

temperature for estimating the influence of past and potential future temperature changes on today's englacial temperature profile. In reality, surface temperatures are the result of the complex energy balance at the snow/atmosphere interface. Air temperature, however, is the only meteorological parameter for which reasonably long-term data series exist. MAAT values were therefore used to estimate effects of changing surfaceboundary conditions. 100 year time series of Grand St. Bernard ( $45^{\circ} 52^{\prime} \mathrm{N}, 2479$ ma.s.l.; main chain of the Alps) and Säntis $\left(47^{\circ} 51^{\prime} \mathrm{N}, 2500 \mathrm{~m}\right.$ a.s.l.; northern slope of the Alps) in Switzerland, and Upernavik $\left(73^{\circ} \mathrm{N}\right)$ in West Greenland are considered here (Smithsonian Institution, 1927, 1934, 1947; U.S. Department of Commerce, 1959, 1968, 1981, 1987; Schüepp, 1961). Deviations from the
100 year average (DMAAT) are plotted in Figure 8. All three records show a trend towards increasing air temperatures at the secular time-scale, with some superimposed shorter-term (decadal) fluctuations. The warming trend, however, is less pronounced at Grand St. Bernard than at Säntis and Upernavik. To reproduce englacial temperature profiles at Colle Gnifetti from the available time series of air temperature, model calculations were run on the assumption of steady-state conditions before 1880 and following the development of $\triangle \mathrm{MAAT}$ at Grand St. Bernard, Säntis and Upernavik for the period 1880-1980 as depicted in Figure 8. No changes in the accumulation rate and the geometry are considered because of lack of information. For the same reason, a steady-state assumption for the period before 1880 has been considered here; somewhat earlier beginning of secular warming at the end of the Little Ice Age may, in fact, have taken place but would only slightly influence the bottom part of the temperature profile (cf. Fig. 10). The effect of a

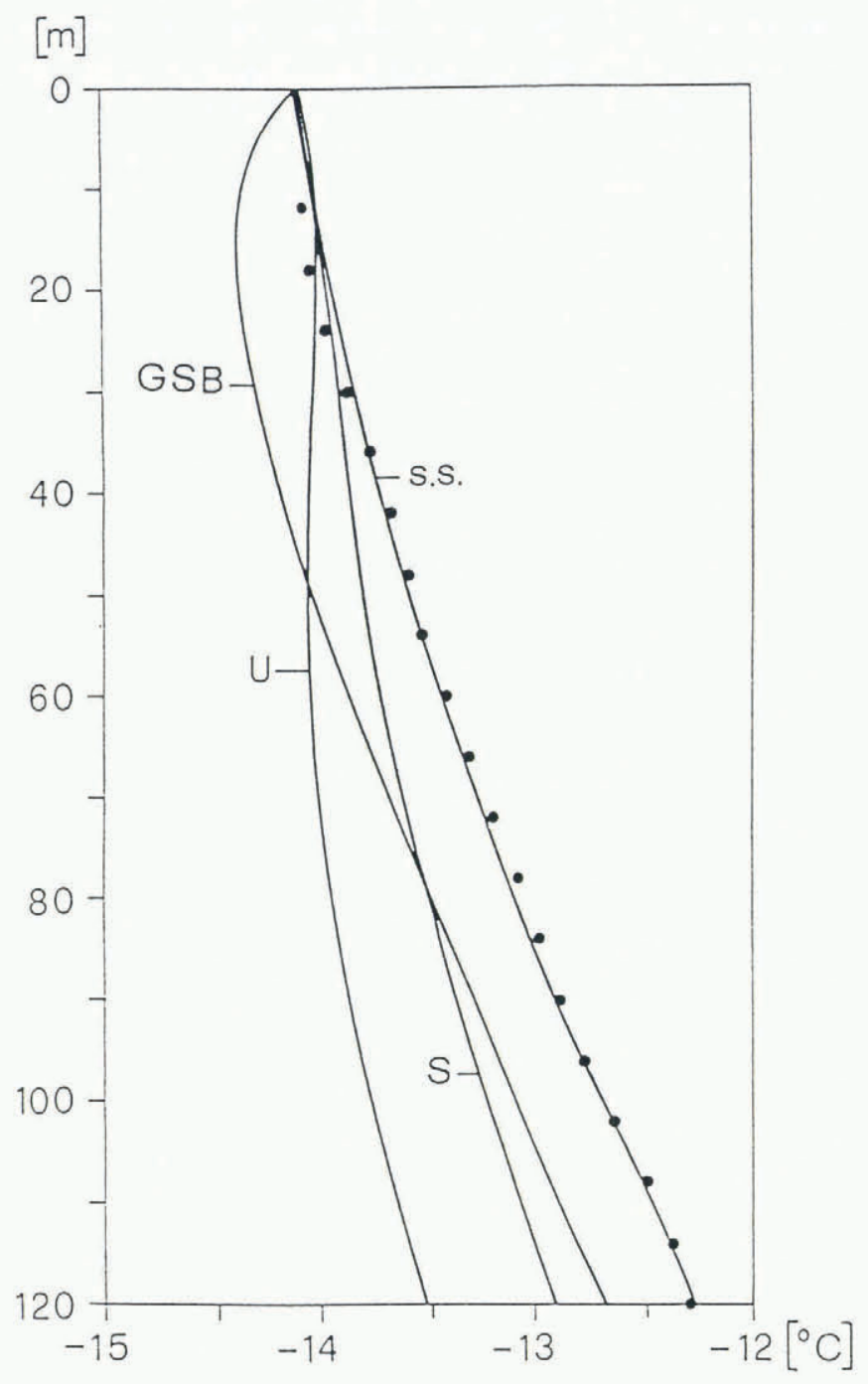

Fig. 9. Measured (dots) and calculated (solid line) englacial temperatures for the drilling site at Colle Gnifetti. The label s.s. indicates the one-dimensional steady-state profile. The labels GSB, $S$ and $U$ indicate time-dependent calculations of firn-temperature profiles according to time series of $\triangle M A A T$ from Grand St. Bernard, Säntis and Upernavik. All calculations are one-dimensional. 
change in the accumulation rate on the temperature profile can be admitted to be small, as shown before. The calculations were performed on the basis of (a) a constant surface temperature $T_{\mathrm{s}}$ (corresponding to the differences between $\triangle$ MAAT $_{1980}, \Delta$ MAAT $_{1880}$ and $T_{\text {s1980 }}$ ) for the time before and up to 1880 to simulate steadystate conditions prior to recent warming trends, and (b) a variable surface temperature according to Figure 8.

Equation (3) was numerically solved with boundary conditions:

$$
\begin{aligned}
T_{\mathrm{s}} & =T_{\mathrm{s}}(t) \\
v_{y}\left(y_{0}\right) & =1 \text { myear }^{-1} \\
K_{\mathrm{i}}\left(\frac{\partial T}{\partial y}\right)_{\mathrm{i}} & =K_{\mathrm{r}}\left(\frac{\partial T}{\partial y}\right)_{\mathrm{r}}
\end{aligned}
$$

with $K_{\mathrm{r}}=3 \mathrm{~W} \mathrm{~K}^{-1} \mathrm{~m}^{-1}$ (Drewry and others, 1984; cf. also Vonder Mühll and Haeberli, 1990) and $K_{\mathrm{i}}=$ $2.1 \mathrm{~W} \mathrm{~K}^{-1} \mathrm{~m}^{-1}$ (at $0^{\circ} \mathrm{C}$; Paterson, 1981 ), where $K_{\mathrm{r}}$ and $K_{\mathrm{i}}$ are the thermal conductivity of bedrock and ice. For the time-dependent case, thermal adjustment of below ground must be taken into account: the bottom boundary condition was therefore displaced from the ice base into the bedrock by a distance (several kilometers) which cannot be reached by surface-temperature variations within the considered time-scale. Figure 9 shows the measured (dots) and the calculated temperature profiles (solid lines). The line labelled s.s. shows the steady-state profile from which the time-dependent calculation for 1880-1980 was started. The lines labelled GSB (Grand St. Bernard), S (Säntis) and U (Uper-

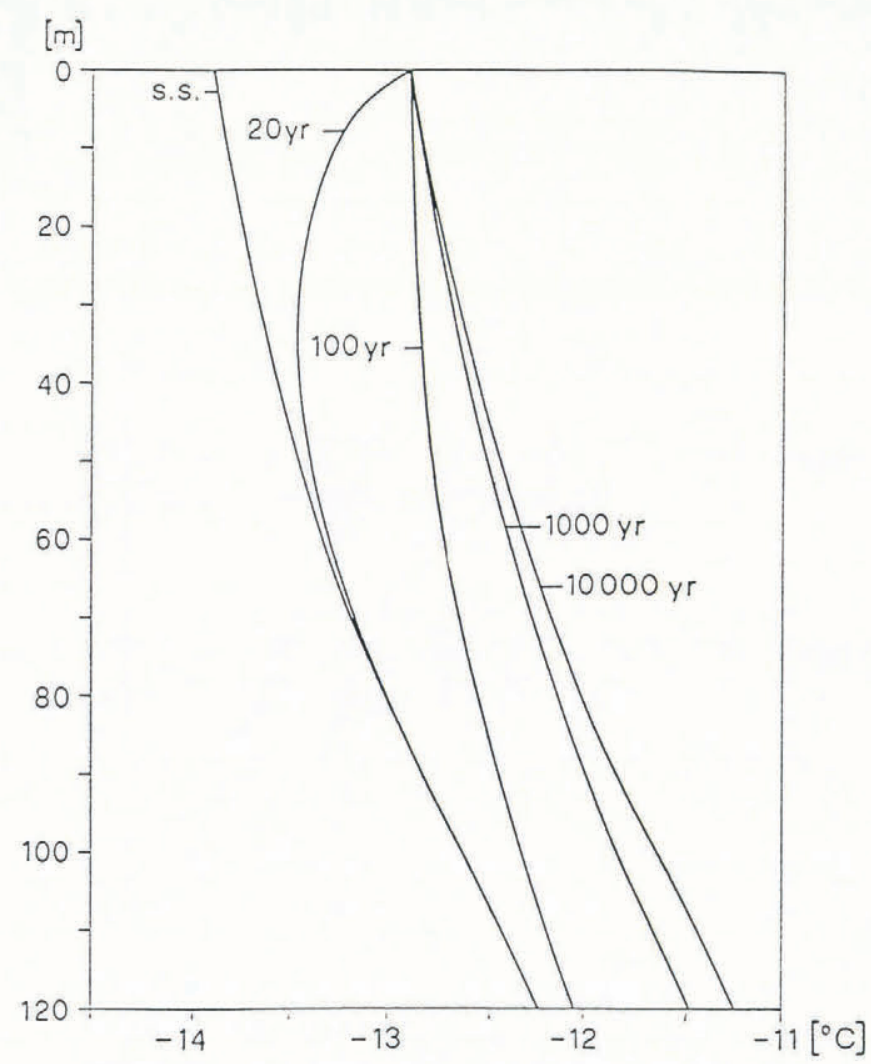

Fig. 10. Measured (dots), steady-state (s.s.) and time-dependent temperature profiles on Colle Gnifetti following an assumed increase of firn-surface temperature by $1^{\circ} \mathrm{C}$ in 20 years until steady-state is reached again; all calculations are one-dimensional.

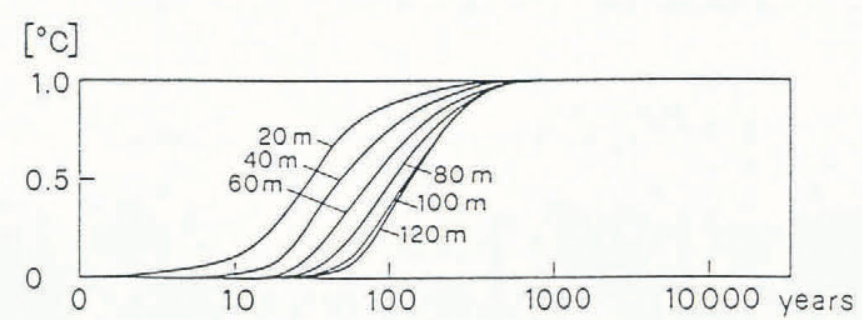

Fig. 11. Temperature-time function for different depths on Colle Gnifetti following a surface-temperature rise of $1^{\circ} \mathrm{C}$ in 20 years until steady state is reached again (onedimensional calculation).

navik) show the calculated profiles for 1980 with the non-stationary boundary condition as explained above. The results illustrate how air-temperature variation in the Northern Hemisphere over the past 100 years would have influenced borehole temperatures at Colle Gnifetti. The temperature profile calculated with the time series from Grand St. Bernard comes closest to the measured profile. This remains true if $\triangle \mathrm{MAFT}$ is assumed to be $1.6 \times \triangle$ MAAT as suggested in connection with altitudinal gradients (Fig. 2). The general offset of the calculated GSB curve from the measured profile is due to most recent effects still hidden within the seasonal temperature fluctuations; below $20 \mathrm{~m}$, however, the profile is parallel to the measured one. This result suggests that mean firn temperature at the Colle Gnifetti drill site closely follows mean air temperature as measured at nearby weather stations and that Grand St. Bernard as well as Colle Gnifetti, both situated in the main chain of the Alps, are predominantly influenced by climatic conditions frequently connected to the Mediterranean area, where 20th century warming was less pronounced (Meyer zu Düttingdorf, 1978). The temperature profiles calculated with the time series from Säntis and Upernavik illustrate effects of stronger secular warming. The corresponding differences in temperature gradient (and, hence, heat flow) with respect to the profile measured on Colle Gnifetti cannot be attributed to measurement uncertainties (cf. Table 1). Enhancing variations in $\triangle \mathrm{MAFT}$ by a factor of 1.6, as discussed above, would make the differences even greater.

Figure 10 shows model calculations of future englacial temperature profiles, assuming that the surface temperature rises by $1^{\circ} \mathrm{C}$ during the 20 years following 1980 and then remains constant. After this surfacetemperature rise, a new steady-state situation will take about 10000 years to be reached. Figure 11 shows the time-dependence of the adaptation to the new steadystate situation for different depths. The calculated rates of temperature changes will be used for the design of a long-term firn-temperature monitoring programme on Colle Gnifetti.

Other scenarios of future warming could easily be considered. Such calculations would, however, not add significantly new aspects to the understanding of potential changes, because a number of uncertainties involved remain obscure. Especially, a better understanding of the interrelation between energy input at the surface, dust deposition, melt-layer formation, protection against 
wind erosion, accumulation and firn temperature should be reached (cf. Alean and others, 1984). Time-dependent balance, geometry and flow would have to be modelled as well as effects of three-dimensional flow. Such efforts require adequate data concerning time variations of glaciological parameters to be collected.

\section{CONCLUSIONS AND PERSPECTIVES}

The borehole measurements given here and model calculations allow one to draw the following conclusions concerning thermal conditions at the Colle Gnifetti coredrilling site:

1. Mean surface temperature of the firn $\left(\right.$ near $\left.-14^{\circ} \mathrm{C}\right)$ is close to mean air temperature.

2. Influence of meltwater in the firn is weak and limited to near-surface melt-layer formation under special conditions of radiation and wind (recrystallizationinfiltration belt of Alpine firn zones).

3. Firn and ice at the saddle borehole and along the flowline leading to it are cold throughout with basal temperatures below $-12^{\circ} \mathrm{C}$ and subglacial permafrost extending into bedrock by probably about $1 \mathrm{~km}$ or more.

4. Mean firn temperatures appear to reflect regional mean air temperatures - in this case as measured at Grand St Bernard in the main chain of the Alps.

5. In contrast to the situation in Arctic firn areas, borehole temperatures measured on Colle Gnifetti are close to steady-state conditions and, hence, do not exhibit striking signs of 20 th century warming.

Attempts to deal with three-dimensional aspects of ice flow are presently being undertaken and detailed measurements of surface processes are also being carried out. A programme for monitoring englacial temperatures is presently being prepared.

\section{ACKNOWLEDGEMENTS}

Thanks are due to a number of colleagues but especially to W. Schmid for assistance in the field and P. Gnos for manufacturing thermistor chains. H. Blatter, A. Iken, J. Schweizer and D. Wagenbach critically commented on the manuscript. We also thank two anonymous referees for helpful suggestions. B. Nedela prepared the drawings, S. à Marca helped with word processing, and S. Braun edited the English.

\section{REFERENCES}

Aellen, M. 1988. Die Gletscher der Schweizer Alpen $1979 / 80$ und $1980 / 81$. Zürich, Gletscherkommission der Schweizerischen Naturforschenden Gesellschaft. (Glaziologisches Jahrbuch 101 and 102.)

Alean, J. 1985. Ice avalanches: some empirical information about their formation and reach. J. Glaciol., 31(109), 324-333.

Alean, J., W. Haeberli and B. Schädler. 1984. Snow accumulation, firn temperature and solar radiation in the area of the Colle Gnifetti core drilling site (Monte Rosa, Swiss Alps): distribution patterns and interrelationships. Z. Gletscherkd. Glazialgeol., 19(2), 131147.
Beck, N., D. Wagenbach and K. O. Münnich. 1988. Laboratory experiments on the formation of solar radiation induced melt layers in dry snow. Z. Gletscherkd. Glazialgeol., 24(1), 31-40.

Blatter, H. 1987. On the thermal regime of an Arctic valley glacier: a study of White Glacier, Axel Heiberg Island, N.W.T., Canada. J. Glaciol., 33(144), 200211.

Blatter, H. and W. Haeberli. 1984. Modelling temperature distribution in Alpine glaciers. Ann. Glaciol., 5, 18-22.

Bodmer, P. and L. Rybach. 1984. Geothermal map of Switzerland (heat flow density). Matér. Géol. Suisse Géophys. 22.

Carslaw, H.S. and J.C. Jaeger. 1959. Conduction of heat in solids. Second edition. Oxford, Clarendon Press.

Drewry, M. J., V.S. Allen and A. M. Jessop. 1984. The measurement of thermal diffusivity of rock cores. Tectonophysics, 103, 321-333.

Fertl, W. H. and P.A. Wichmann. 1977. How to determine static BHT from well log data. World Oil, January, 105-106.

Fisher, J. E. 1953. The cold ice tunnel on the Silbersattel, Monte Rosa. Preliminary report. J. Glaciol., 2(13), 195-196.

Fisher, J. E. 1954. The cold ice tunnel on the Silbersattel, Monte Rosa. 1953 progress. J. Glaciol., 2(15), 341.

Fisher, J. E. 1955. Internal temperatures of a cold glacier and conclusions therefrom. J. Glaciol., 2(18), 583591.

Haeberli, W. 1976. Eistemperaturen in den Alpen. Z. Gletscherkd. Glazialgeol., 11(2), 1975, 203-220.

Haeberli, W. and J. Alean. 1985. Temperature and accumulation of high altitude firn in the Alps. Ann. Glaciol., 6, 161-163.

Haeberli, W., U. Schotterer, D. Wagenbach, H. HaeberliSchwitter and S. Bortenschlager. 1983. Accumulation characteristics on a cold, high-Alpine firn saddle from a snow-pit study on Colle Gnifetti, Monte Rosa, Swiss Alps. J. Glaciol., 29(102), 260-271.

Haeberli, W., W. Rellstab and W.D. Harrison. 1984. Geothermal effects of $18 \mathrm{ka} \mathrm{BP}$ ice conditions in the Swiss plateau. Ann. Glaciol., 5, 56-60.

Haeberli, W., W. Schmid and D. Wagenbach. 1988. On the geometry, flow and age of firn and ice at the Colle Gnifetti core drilling site (Monte Rosa, Swiss Alps). Z. Gletscherkd. Glazialgeol., 24(1), 1-19.

Herron, M. M. and C. C. Langway, Jr. 1980. Firn densification: an empirical model. J. Glaciol., 25(93), 373-385.

Koerner, R. M. 1977. Devon Island ice cap: core stratigraphy and paleoclimate. Science, 196(4285), 15-18.

Ling, C.-H. 1985. A note of the density distribution of dry snow. J. Glaciol., 31(108), 194-195.

Lliboutry, L., M. Briat, M. Creseveur and M. Pourchet. 1976. $15 \mathrm{~m}$ deep temperatures in the glaciers of Mont Blanc (French Alps). J. Glaciol., 16(74), 197-203.

Meyer zu Düttingdorf, A. M. 1978. Klimaschwankungen im maritimen und kontinentalen Raum Europas seit 1871. Bochumer Geogr. Arb. 32. 
Mitchell, A.R. and D.F. Griffiths. 1980. The finite difference method in partial differential equations. New York, Wiley and Sons.

Morton, K. W. 1980. Stability of finite difference approximations to a diffusion-convection equation. Int. J. Numer. Methods Eng., 15, 677-683.

Oeschger, H., U. Schotterer, B. Stauffer, W. Haeberli and H. Röthlisberger. 1978. First results from Alpine core drilling projects. Z. Gletscherkd. Glazialgeol., 13(1/2), 1977, 193-208.

Paterson, W.S. B. 1981. The physics of glaciers. Second edition., Oxford, etc., Pergamon Press.

Ritz, C. 1987. Time dependent boundary conditions for calculation of temperature fields in ice sheets. International Association of Hydrological Sciences Publication 170 (Symposium at Vancouver 1987 The Physical Basis of Ice Sheet Modelling), 207216.

Robin, G. de Q., ed. 1983. The climatic record in polar ice sheets. Cambridge, etc., Cambridge University Press.

Runchal, A. K. 1972. Convergence and accuracy of three finite-difference schemes for a two-dimensional conduction and convection problem. Int. J. Numer. Methods Eng., 4, 541-550.

Schotterer, U., W. Haeberli, W. Good, H. Oeschger and H. Röthlisberger. 1981. Datierung von kaltem Firn und Eis in einem Bohrkern vom Colle Gnifetti, Monte Rosa. Jahrb. Schweiz. Naturforsch. Ges. Wiss. Teil, 1978, 48-57.

Schotterer, U., H. Oeschger, D. Wagenbach and K. O. Münnich. 1985. Information on paleo-precipitation on a high-altitude glacier, Monte Rosa, Switzerland. Z. Gletscherkd. Glazialgeol., 21, 379-388.

Schüepp, M. 1961. Klimatologie der Schweiz, Heft 2/C. Lufttemperatur. 2. Teil. Annalen der Schweizerischen Meteorologischen Zentralanstalt. Beiheft, 1960.

Schweizer, J. 1988. Numerische Analyse eines Hängegletschers am Lyskamm (Walliser Alpen). Eidg. Tech. Hochschule, Zürich. Versuchsanst. Wasserbau, Hydrol. Glaziol. Mitt. 94, 371-386.

Smith, G.D. 1978. Numerical solution of partial differential equations: finite difference methods. Second edition. Oxford, Clarendon Press.
Smithsonian Institution. 1927. World weather records, -1920. Smithson. Misc. Collect., 79. (Publication 2913.)

Smithsonian Institution. 1934. World weather records, 1921-1930. Smithson. Misc. Collect., 90. (Publication 3216.)

Smithsonian Institution. 1947. World weather records, 1931-1940. Smithson. Misc. Collect., 105. (Publication 3803.)

U.S. Department of Commerce. 1959. World weather records, 1941-1950. Washington, DC, U.S. Department of Commerce. Weather Bureau.

U.S. Department of Commerce. 1968. World weather records, 1951-1960. Washington, DC, U.S. Department of Commerce. Environmental Science Services Administration.

U.S. Department of Commerce. 1981. World weather records, 1961-1970. Washington, DC, U.S. Department of Commerce. National Oceanographic and Atmospheric Administration.

U.S. Department of Commerce. 1977. World weather records, 1971-1980. Washington, DC, U.S. Department of Commerce. National Oceanographic and Atmospheric Administration.

Vonder Mühll, D. and W. Haeberli. 1990. Thermal characteristics of the permafrost within an active rock glacier (Murtèl/Corvatsch, Grisons, Swiss Alps). J. Glaciol., 36(123), 151-158.

Waddington, E. D. 1987. Geothermal heat flux beneath ice sheets. International Association of Hydrological Sciences Publication 170 (Symposium at Vancouver 1987 - The Physical Basis of Ice Sheet Modelling), 217-226.

Wagenbach, D. 1989. Environmental records in alpine glaciers. In Oeschger, H. and C.C. Langway, Jr, eds. The environmental record in glaciers and ice sheets. Chichester, etc., Wiley and Sons, 69-83.

Wagenbach, D., K.O. Münnich, U. Schotterer and H. Oeschger. 1988. The anthropogenic impact on snow chemistry at Colle Gnifetti, Swiss Alps. Ann. Glaciol., 10, 183-187.

The accuracy of references in the text and in this list is the responsibility of the authors, to whom queries should be addressed. 